\title{
The Development of Company Profile Website for CV. Rian using Waterfall Model SDLC
}

\author{
${ }^{1}$ IRMA AMELIA DEWI , ${ }^{2}$ LISYE FITRIA, ${ }^{2}$ ARIE DESRIANTY, ${ }^{2}$ ALIF ULFA AFIFAH, \\ ${ }^{1}$ M. FAISHAL DZAKY \\ ${ }^{1}$ Informatika, Institut Teknologi Nasional Bandung, \\ ${ }^{2}$ Teknik Industri, Institut Teknologi Nasional Bandung \\ Email: irma amelia@itenas.ac.id
}

Received 25 November 2020 | Revised 29 November 2020 | Accepted 30 November 2020

\begin{abstract}
Nowadays, the benefits of using the internet can be felt in society or even in the industrial world, either for business or just for entertainment purposes. Until 2017, Indonesia is one of the countries with the highest internet users globally, with around 112,6 million internet users. On the other hand, many small businesses have not used the internet to advertise their products. This project's main objective is to design and develop a company profile website of CV Rian as one of the brick micro-industry in Nagrek, West Java, enabling people to search and access information easily and quickly. This project uses Waterfall Model as Sofware Development Life Cycle (SDLC), MySQL as the database, and PHP for server-side scripting. The database is used for storing posts, admin data, and images.
\end{abstract}

Keywords: company profile, brick industry, Waterfall, micro-industry

\section{INTRODUCTION}

Indonesia, as a developing country, is very concerned about the process of national and economic development. The positive impact of economic growth in Indonesia is developing adequate housing for all groups of society, constructing new healthier settlements and the availability of adequate facilities and infrastructure, and environmental improvement through settlement development. Therefore, business activists engaged in providing construction materials or services are growing and growing. One of the materials required in building construction is bricks for constructing office buildings, public facilities, and residential houses, especially in big cities with a vast building development trend.

Companies' competition that manufacture bricks also increased due to buildings' construction is increasingly widespread in every major city. Therefore, companies must produce good quality products according to customer desires and sell their products at affordable prices to compete. Thus, the company must consider the strategy for determining the selling price of its products. This price determination is one-factor choosing competition in the market with similar industries

(Irawan \&

Pamungkas, 2019). 
Competition in the brick production industry is increasing, starting from the micro-industry to the macro-industry. The micro-industry requires a strategy to stay in the market or remain competitive with other competitors. For example, West Java's micro-industry, a center for brick production, is quite well known, precisely in the Nagreg area. This area is one of the centers for craftsmen of red bricks, which is cheap but has a fairly good quality, although the process is still manual without a machine's aid. Residents in the Nagreg area have been able to utilize the natural resources around them for their livelihoods. Some people have made the production of bricks become a primary means of livelihood, one of which is CV Rian, which produces bricks in Nagrek, West Java.

The habits of today's people who want the ease of accessing information quickly and easily cannot be separated from the use of gadgets and internet access so that this can be used as a solution to support CV Rian's marketing strategy. Indonesia is one of the countries with the highest internet users in the world. Until 2017, There are about 112,6 million internet users in Indonesia (Setti \& Wanto, 2018). On the other hand, many small businesses have not used the internet to advertise their products, so their market is limited.

This community service provides CV Rian solutions as a micro-industry by creating a company profile website from the aforementioned problem. With this website, we hope that consumers could easily access the business and extend the market furthermore. Currently, company profiles are made in such a way as to increase selling value; some are in the form of videos, websites, prints, and even an interactive company profile. So that in this community service activity, one of the proposed ways to promote and market CV Rian's products is to apply IT technology by developing a company profile website that contains history, information, and pictures of the products produced and company contacts. The company profile website design for CV Rian was designed using Waterfall as a Software Development Life Cycle (SDLC) because this model is easy to manage in particular for developing this system because there is no need for a lot of features.

\section{METHODOLOGY}

This project's main focus is to create a company profile website that describes the company and show their products. The development of this system uses the Software Development Life Cycle (SDLC) method called Waterfall.

There are six phases to do in designing software using the Waterfall method, which are feasibility study, software planning and requirement, analysis, detailed design, coding, and system integration. The details of the Waterfall method are shown in Figure 1.

\subsection{Feasibility Study}

The software engineer team comes up with the next software process plan to analyze if software can be designed to fulfill all user requirements and any possibility of software being no more useful (Sharma, 2017).

\subsection{Software Planning and Requirement}

This phase starts with the software engineers to collect all user requirements to carry on software development. The software developing team holds discussions with the users for a problem and tries to bring out as much information as possible on their requirements (Sharma, 2017). 
In this project, after discussing with the user's several requirements need to be fulfilled, which are:

1. The website shows its profile, including the logo, address, e-mail, phone number, and history.

2. The website shows the descriptions of what product they are selling.

3. The website shows why their product is worth to buy.

4. The website shows the company images gallery.

5. The website has a form to e-mail the company directly.

6. The website has a login system to the administrator dashboard.

7. The administrator can upload or delete images.

8. The administrator can edit company contacts and contents on the website.

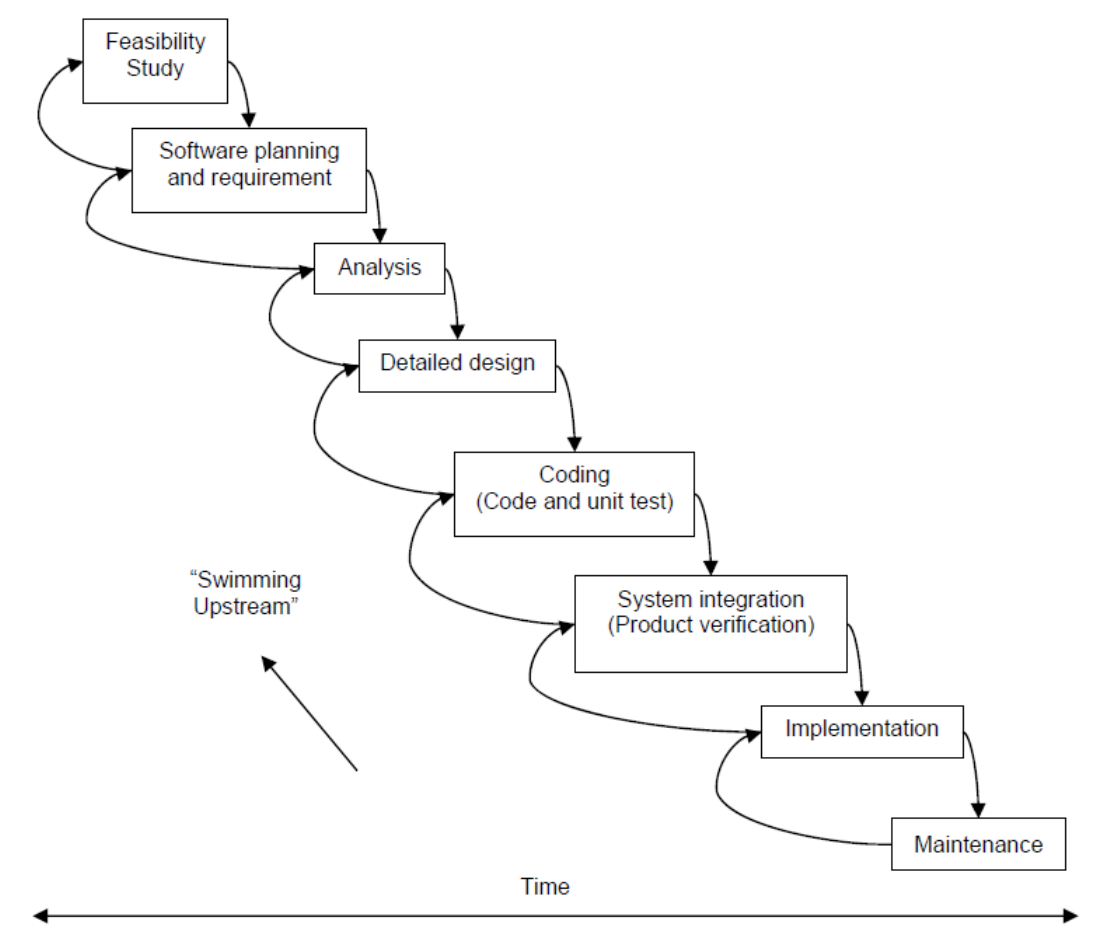

Figure 1. Waterfall Model SDLC (Khan, Shadab, \& Khan, 2020)

\subsection{Analysis}

The software engineer team should analyze the software user requirements, remove anomalies, error or not required information from specifications, plan, and bring up the best software model suitable for the project (Sharma, 2017).

According to requirements in point 2.2, the website could be created in 6 pages: the home page, gallery page, contact page, login page, and administrator page. The details of every page shown in Figure 2.

\subsection{Detailed Design}

This phase is to bring down whole knowledge of requirements and analysis for designing the software. Various designs like functional design and object-oriented design are available for creating software products (Sharma, 2017). 


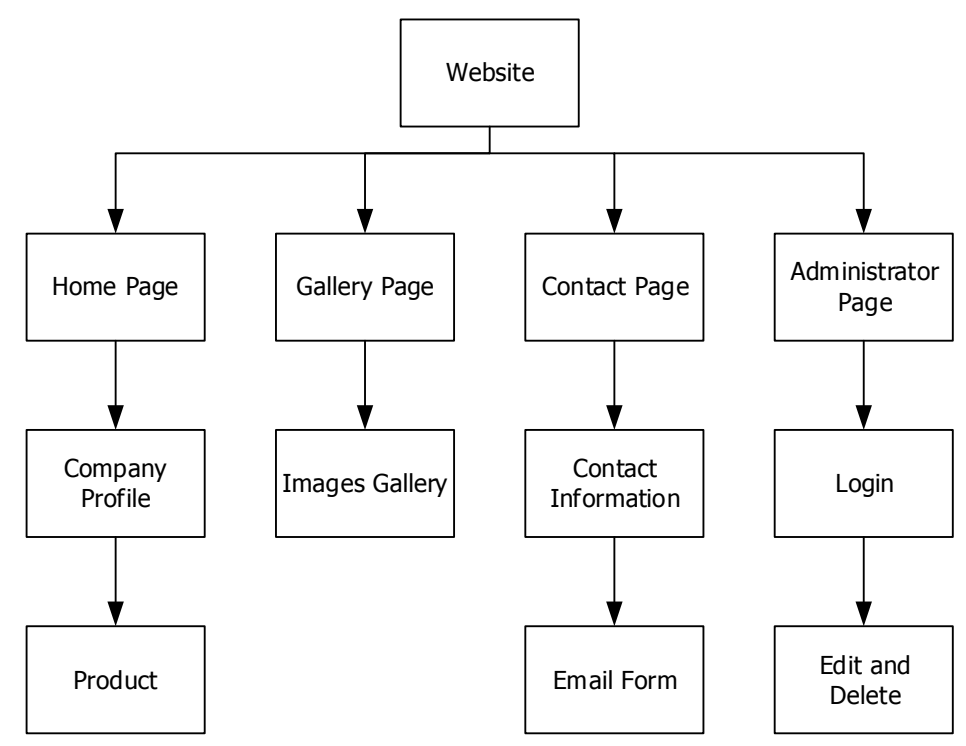

Figure 2. Sitemaps

\subsubsection{UML Design}

Unified Modeling Diagram (UML) is a graphical language for visualizing, specifying, constructing, and documenting a software-intensive system's artifacts. It offers a standard way to write a system's blueprints, including conceptual things such as business processes and system functions and tangible items such as programming statements, database schemas, and reusable software components. UML has 14 types of diagrams divided into multiple categories (Padmanabhan, 2012).

In this project, we will only use two types of UML diagrams, which are use case diagram and sequence diagram.

\subsubsection{Use Case Diagram}

In the use case modeling approach, functional requirements are described in terms of actors, users of the system, and use cases. A use case defines a sequence of interactions between one or more actors and the system (Gomaa, 2011).

In this project, two actors are the site user and administrator. The administrator actor could manage gallery and company details, and the site user actor could only view the homepage, gallery page, and contact page. UML use case diagram represented in Figure 3.

\subsubsection{Sequence Diagram}

A sequence diagram is developed based on a particular use case scenario encompassing both basic and alternative flows (Kurniawan, Le, \& Priyambadha, 2020).

A sequence diagram for the administrator login system is represented in Figure 4. 
The Development of Company Profile Website for CV. Rian using Waterfall Model SDLC

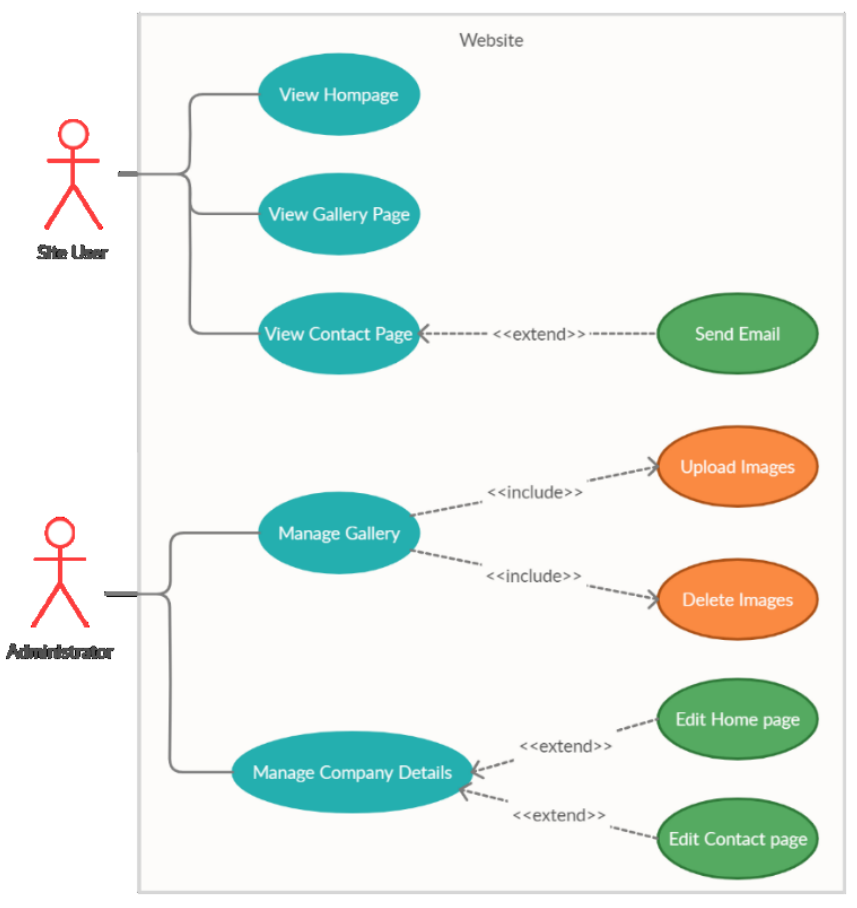

Figure 3. UML Use Case Diagram

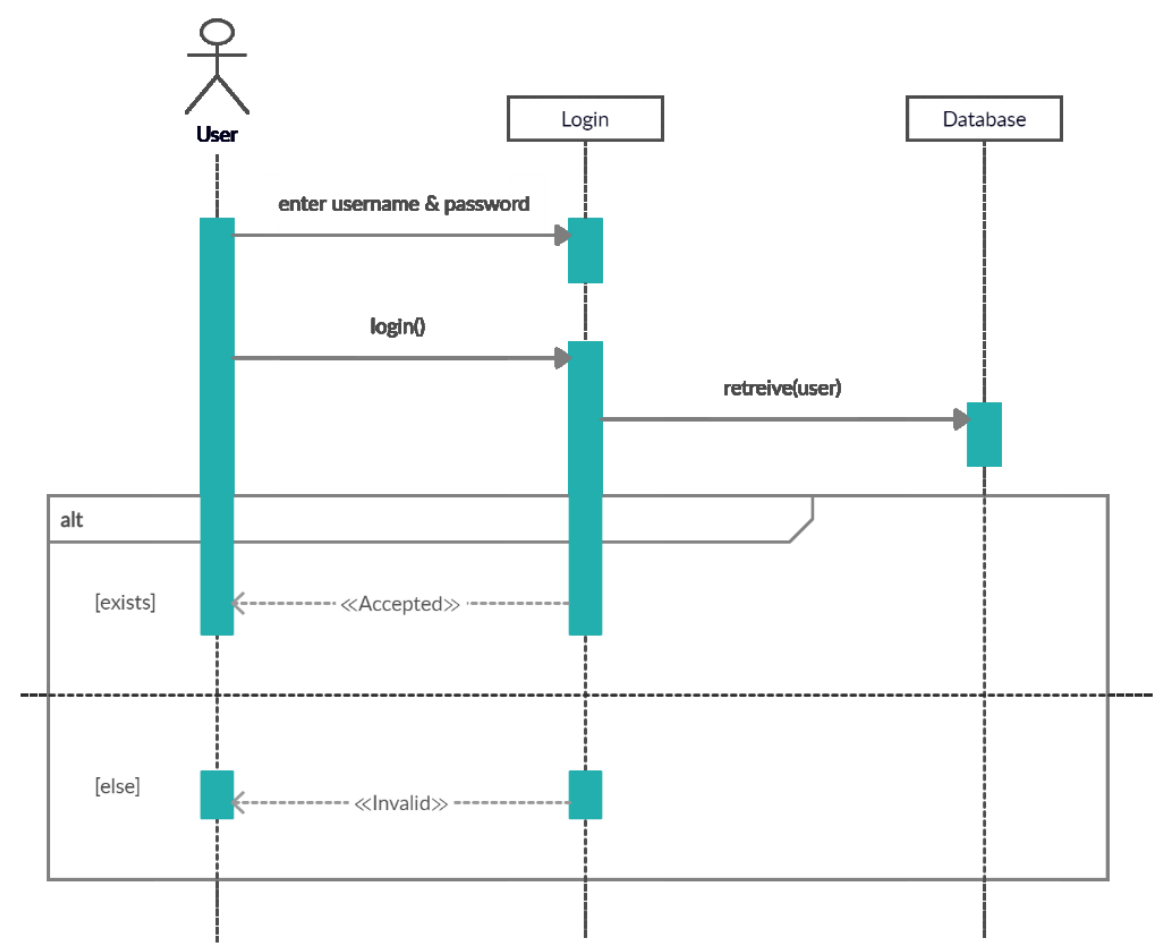

Figure 4. Sequence Diagram

\subsubsection{Database Design}

The database is a compiled collection of related data, organized and stored systematically in computer storage. It refers to particular methods that can be accessed fastly and easily 
The Development of Company Profile Website for CV. Rian using Waterfall Model SDLC

using a computer program/application to obtain data from the database (Ichwan, 2011). In this 
project, we are using a relational database and using MySQL DBMS. The company profile website contains posts and an image gallery. To edit posts, edit gallery or upload images, the user needs to be logged in as an administrator.

\subsubsection{Entity Relationship Diagram}

Database systems are often modeled using an Entity-Relationship (ER) diagram as the blueprint from which the actual data are stored,the blueprint is the output of the design phase. The ER diagram is an analyst's tool to diagram the data to be stored in a database system (Bagui \& Earp, 2012).

According to requirements in point 2.2, the database could be created in four-post, post_type, admin, and gallery. The details of database entities and it's relation represented in Figure 5.

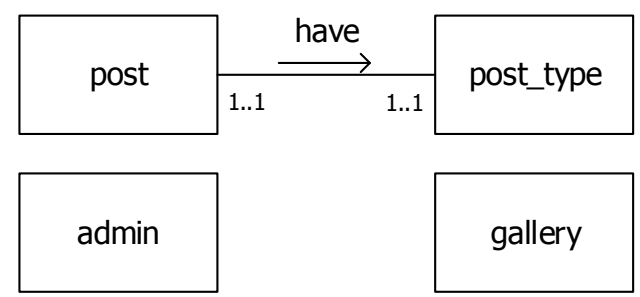

Figure 5. Entity Relationship Diagram (ERD)

\subsubsection{Table Relationship Diagram}

Based on four database entities created in the ERD section, every entity could be created and filled with attributes represented in Figure 6.
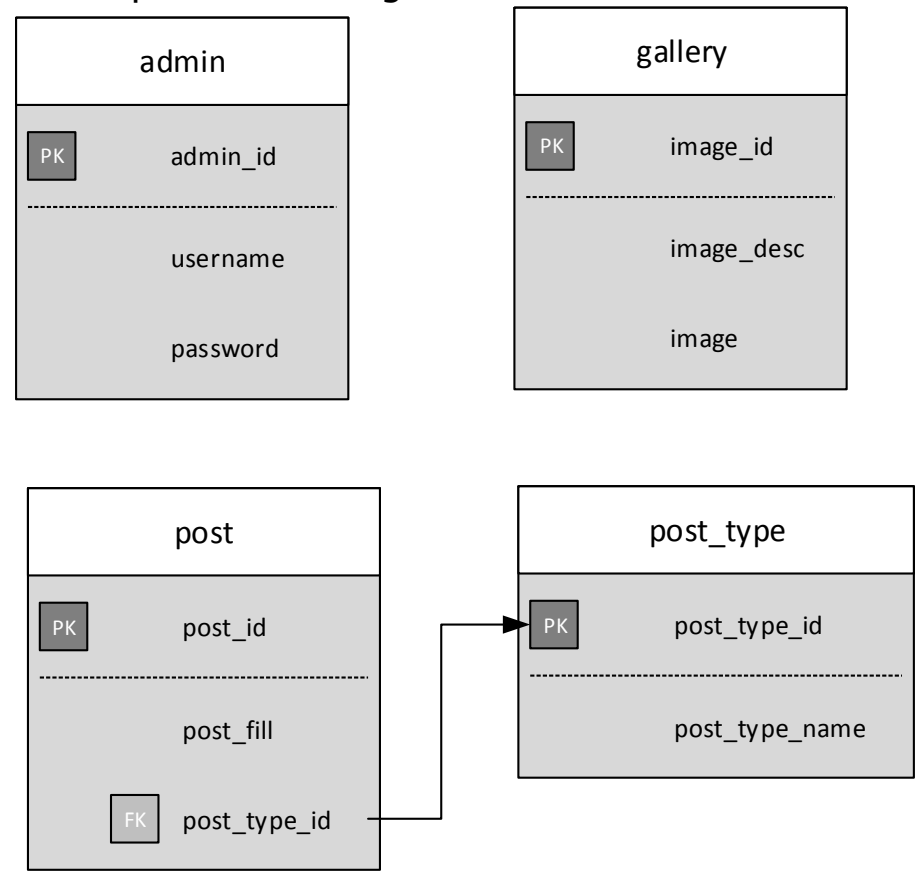

Figure 6. Table Relationship Diagram (TRD)

\subsubsection{Data Description Specification}

Data description specifications explain every attributes from every table. Data descriptions specifications are shown in Table 1. 
Table 1. Data Description Specification (DDS)

\begin{tabular}{|c|c|c|c|}
\hline $\begin{array}{l}\text { Attribute } \\
\text { Name }\end{array}$ & Data Type & Length & Descriptions \\
\hline admin_id (PK) & Integer & 1 & admin id is used for the primary key in the admin table \\
\hline image_id & Integer & 3 & image_id is used for primary key in gallery table \\
\hline image_desc & Text & - & image_desc is used for alternative image name \\
\hline image & Varchar & 60 & $\begin{array}{l}\text { Image is used for pointing the location of images that } \\
\text { stored in the FTP server }\end{array}$ \\
\hline post_fill & Text & - & $\begin{array}{l}\text { post_fill is used for storing words or numbers that } \\
\text { wanted to be shown on the website }\end{array}$ \\
\hline post_id & Integer & 11 & post_id is used for primary key in post table \\
\hline post_type_id & Integer & 2 & $\begin{array}{l}\text { post_type_id is used for the primary key in the } \\
\text { post_type table and as a foreign key in the post table }\end{array}$ \\
\hline post_type_name & varchar & 10 & post_type_name is used for classify the type of a post \\
\hline
\end{tabular}

\subsection{Coding}

This phase is also known as programming or coding phase. The practical development of software design starts with writing program code in the suitable programming language and developing error-free executable programs efficiently (Sharma, 2017).

In this project, we are using four languages which are PHP, HTML, CSS, and Javascript. PHP is used as middleware between server and client to retrieve and store data into a database. We use an Atom text editor to create and edit PHP files. HTML is used as a markup language to create the base interface of the website. We use an Atom text editor to create and edit HTML files. CSS is used as a styling language to enhance the interface of the website built in HTML. We use an Atom text editor to create and edit CSS files. Javascript is used as programming language that runs any animations on the website. We use an Atom text editor to create and edit Javascript files.

\section{RESULTS AND DISCUSSION}

The system testing phase is a step used to make sure that the system is working well. System testing using black-box testing focused on functional software requirements. In black-box testing, it allows the developer to get a set of inputs that will do all system applicable requirements (Wahyunningrum \& Januarita, 2015).

System testing is done by testing: home page, gallery page, contact page, login page, and administrator page.

Home Page

Table 2. Home Page Testing

\begin{tabular}{|c|l|c|c|}
\hline \multicolumn{4}{|c|}{ Home Page Test Result } \\
\hline Input & \multicolumn{1}{|c|}{ Expected } & Observation Result & Conclusion \\
\hline- & $\begin{array}{l}\text { The system can show } \\
\text { a page with a title, } \\
\text { subtitle, product } \\
\text { descriptions, and logo }\end{array}$ & System working well & OK \\
\hline
\end{tabular}




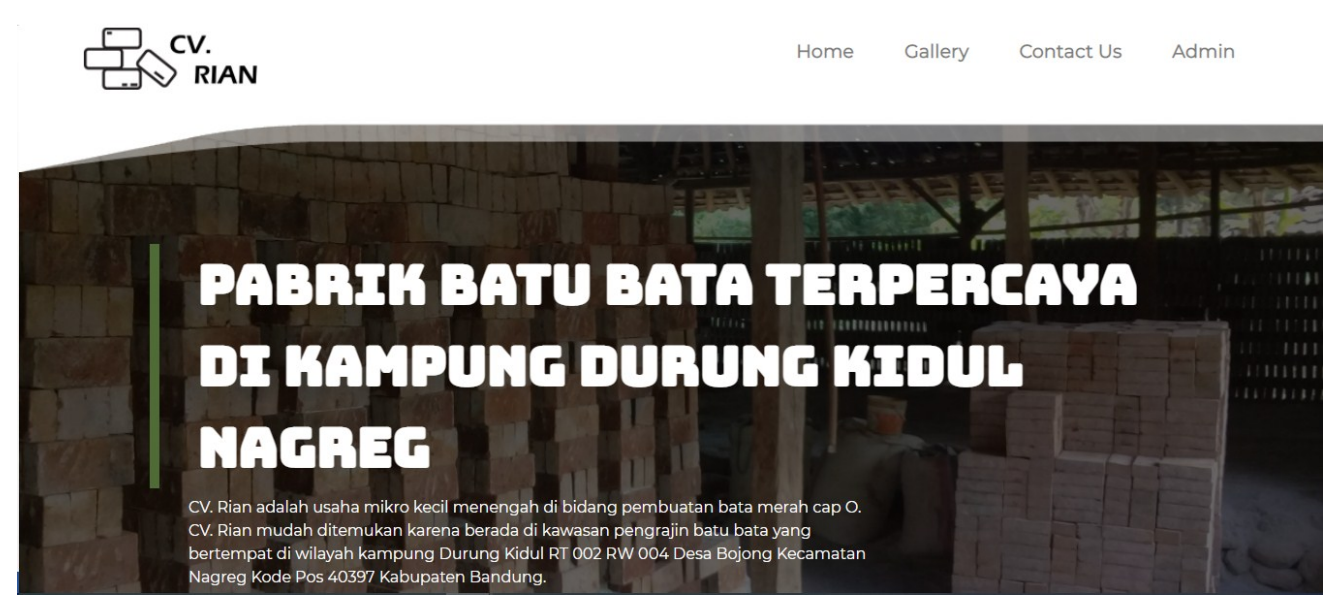

Figure 7. Home Page

In the first test conducted in functionality to the home page, testing is carried out by checking the system's success displays the home page elements. The testing scenario can be seen in Table 2, and the image result can be seen in Figure7.

\section{Gallery Page}

Table 3. Gallery Page Testing

\begin{tabular}{|c|l|c|c|}
\hline \multicolumn{4}{|c|}{ Gallery Page Test Result } \\
\hline Input & \multicolumn{1}{|c|}{ Expected } & Observation Result & Conclusion \\
\hline- & $\begin{array}{l}\text { The system can } \\
\text { images gallery }\end{array}$ & System working well & OK \\
\hline
\end{tabular}

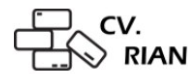

\section{OUR GALLERY}
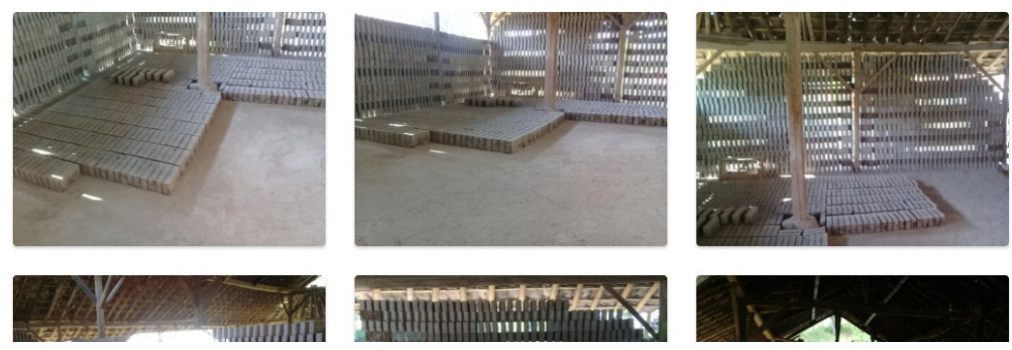

Figure 8. System Showing Gallery

The functionality testing also was performed on the Gallery menu. The testing is carried out by clicking the Gallery Menu, and the system successfully displayed all product's images as in Figure 8. 


\section{Contact Page}

Table 4. Contact Page Testing

\begin{tabular}{|c|l|c|c|}
\hline \multicolumn{4}{|c|}{ Contact Page Test Result } \\
\hline Input & \multicolumn{1}{|c|}{ Expected } & Observation Result & Conclusion \\
\hline- & $\begin{array}{l}\text { The system can show } \\
\text { phone number, e-mail, } \\
\text { and form }\end{array}$ & System working well & OK \\
\hline E-mail Form & $\begin{array}{l}\text { The system can send } \\
\text { an e-mail directly } \\
\text { through the e-mail } \\
\text { form }\end{array}$ & E-mail received & OK \\
\hline
\end{tabular}

CSCV. RIAN

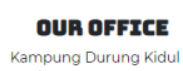

Kampung Durung Kidul $r$

Nagreg
Najo
Calnus us

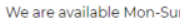

$8 a m-8 p m$
EMArL Us

uchulld21@gmail.com

Figure 9. System Showing Contacts and Form

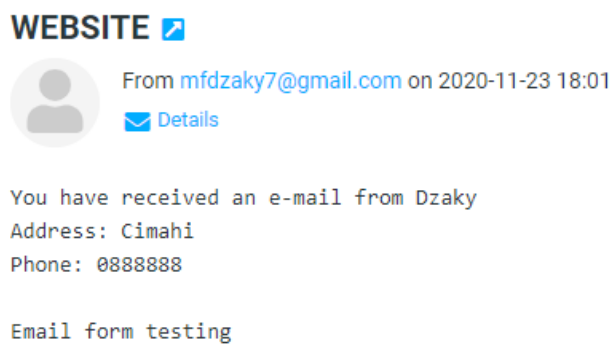

From mfdzaky7@gmail.com on 2020-11-23 18:01

$\checkmark$ Details

You have received an e-mail from Dzaky

Address: Cimahi

Phone: 0888888

Email form testing

Figure 10. E-mail Received

The testing on the Contact us Menu was performed with two scenarios. The system can display the Contact us page correctly and send an e-mail directly through the e-mail form, as shown in Figure 10.

\section{Login Page}

Table 5. Login Page Testing

\begin{tabular}{|c|l|l|l|}
\hline \multicolumn{4}{|c|}{ Login Page Test Result } \\
\hline Input & \multicolumn{1}{|c|}{ Expected } & Observation Result & \multicolumn{1}{c|}{ Conclusion } \\
\hline $\begin{array}{c}\text { Username and } \\
\text { Password }\end{array}$ & $\begin{array}{l}\text { The system can } \\
\text { identify who can open } \\
\text { the administrator page } \\
\text { and not }\end{array}$ & $\begin{array}{l}\text { Administrator logged } \\
\text { in and non- } \\
\text { administrator can not } \\
\text { login }\end{array}$ & OK \\
\hline
\end{tabular}

Reka Elkomika-84 


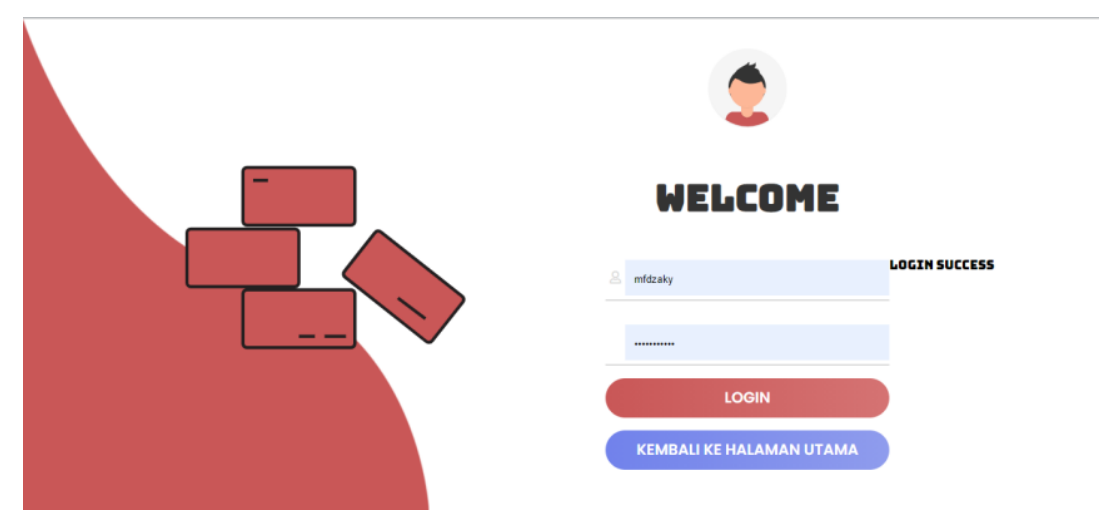

Figure 11. Administrator Logged in

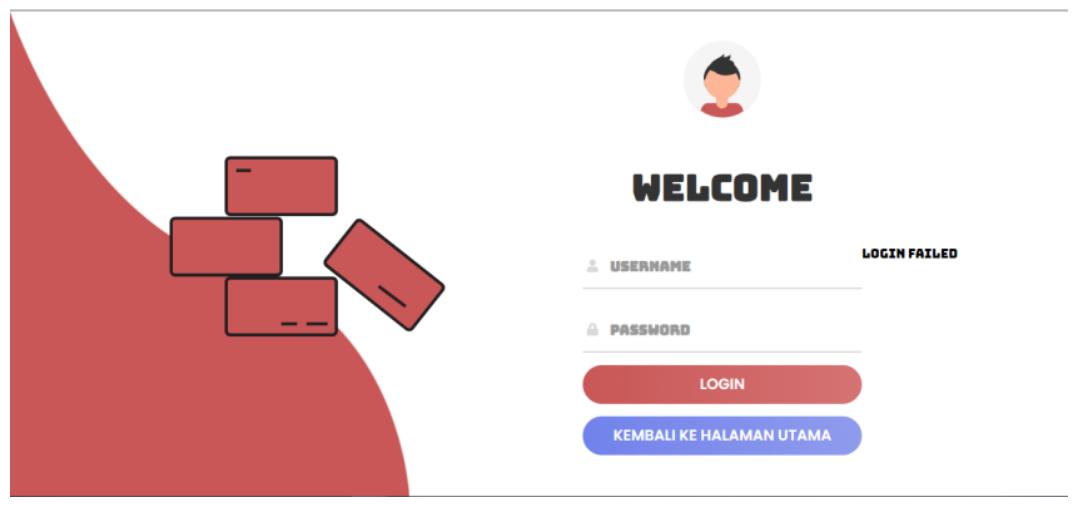

Figure 12. Non-administrator Login Failed

This system is built with features for the owner to add information or add product images to display on the front-end page, as shown in Figure 11 and Figure 12.

\section{CONCLUSIONS}

Using the internet is very beneficial, especially for the industrial or business world. A website can make the gap closer between company and consumer, so the communication between company and consumer would be smoother, and help the market of a company would be extended.

\section{ACKNOWLEDGEMENT}

This community service is fully funded by Institute for Research and Community Services or LPPM (Lembaga Penelitian dan Pengabdian Kepada Masyarakat) of Itenas Bandung in 2020.

\section{LIST OF REFERENCES}

Bagui, S., \& Earp, R. (2012). Database Design Using Entity Relationship Diagrams. Boca Raton: CRC Press.

Gomaa, H. (2011). Software modeling and design: UML, use cases, patterns, and software architectures. Cambridge: Cambridge University Press. 
Ichwan, M. (2011). Pemrograman Basis Data Delphi 7 \& MySQL. Bandung: INFORMATIKA. Irawan, H. T., \& Pamungkas, I. (2019). PENETAPAN HARGA JUAL BATU BATA PADA UD. BATA JAYA DENGAN MENGGUNAKAN METODE TARGET PROFIT PRICING. Jurnal Optimalisasi Volume 5 Nomor 1, 1-9.

Khan, M., Shadab, S., \& Khan, F. (2020). Empirical Study of Software Development Life Cycle and its Various Models. International Journal of Software Engineering (IJSE), Volume (8) : Issue (2), 16-26.

Kurniawan, T. A., Le, L.-S., \& Priyambadha, B. (2020). Challenges in Developing Sequence Diagrams. JITeCS, 221-234.

Padmanabhan, B. (2012). Unified Modeling Language (UML) Overview. EECS.

Setti, S., \& Wanto, A. (2018). Analysis of Backpropagation Algorithm in Predicting the Most Number of Internet Users in the World. JOIN, 110-111.

Sharma, M. K. (2017). A Study of SDLC to Develop Well Engineered Software. International Journal of Advanced Research in Computer Science, 520-523.

Wahyunningrum, T., \& Januarita, D. (2015). Implementasi dan Pengujian Web E-commerce untuk Produk Unggulan Desa. Jurnal Politeknik Caltex Riau, 57-66. 